\title{
The Factors Determining the Creativity of the Human Capital in the Conditions of Sustainable Development
}

\author{
Ph.D Monika Sipa ${ }^{1}$
}

\begin{abstract}
:
Sustainable development and innovativeness are challenges which contemporary enterprises and economies have to face. The increase in the innovativeness requires proper resources, in particular, creative and innovative human capital towards whom principles of responsibility are applied. Broadening the knowledge on the subject of creativity processes, creation and innovativeness will allow for the accomplishment of more productivity of human resources in the enterprise. Capital of knowledge and innovative capital will be more considerable. The main goal of the compilation was, therefore, to identify the factors determining creativity and innovativeness of labour resources in Polish and Slovakian economic entities. An analysis was conducted which allowed for the indication of both similarities and differences occurring in this area within the examined countries. The conclusions were based on the author's own research which was carried out in the first quarter of 2017.
\end{abstract}

Key words: creativity, buman capital, innovativeness enterprises, sustainability development.

\section{Introduction}

Sustainable development is today the main principle of long-term development of states, regions and organisations. Sustainable development of an enterprise occurs when it actively takes care of its external environment as well as its internal sub-systems so that their supporting capabilities can be recreated. The priorities of its development take into account relationships with its stakeholders, environmental care and cooperation with non-governmental organisations, and in particular relationships with employees. One of the routes towards sustainable development is through innovations, which may take different forms, but only them can ensure an enterprise sustainable development, making contribution to sustainable development of the whole economy (Mynarzova, Stverkova, 2015).

Creativity and innovativeness are of key importance, both at micro, macro and society levels. Taking into account creativity in estimation of Global Innovation Index (GII) confirms its role in increasing innovativeness (Lanvin, Evans, 2015) Creative thinking can be regarded as the first step towards innovation, as innovations are successful implementation of creative ideas (Van de Ven, 1986). However, we should bear in mind that not every effect of a creative process will be innovation, as many ideas will undoubtedly be rejected in a decision-making process (Jerzyk, Leszczyński, Mruk, 2004). In order to increase their innovativeness, enterprises have to be learning organisations, which consistently create new knowledge, spreading it across the whole organisation and 
quickly transforming into new technologies and products (Nonaka, Takeuchi, 2000). In response to constant changes taking place on the markets and in technologies companies have to develop capabilities and competences necessary for adaptation and reorganisation of their environment (Gorzeń-Mitka, 2016). Therefore, the human resources and the company's management, strategy and organization are essential elements.(OECD, 1997).

Human capital is treated as a very important factor in the development of economies and individual organisations. A strong relationship is pointed out between investment in human capital and economic transformations of a country. People with higher level of education show more entrepreneurship and initiative (Król, Ludwiczyński, 2006; Betakova, Dvorsky, Haviernikova, 2014). A key element in increasing innovativeness of organisations is their staff, who constitute both an important resource and capital of an organisation. These assets to a large extent contribute to the development of a company's value, as human behaviours underlie effective implementation of defined strategic objectives. In the face of increased competition, they not only constitute a crucial resource of business but are also considered as the basis of differentiation creation between firms.

At a time when increasing attention is paid to the development of social capital, principles of responsibility towards employees are a key factor. Good working conditions and a friendly atmosphere among employees have a direct impact on employees' creativity, effectiveness and loyalty. Managers of organisations should focus on ensuring conditions that can stimulate creativity and facilitate organisational learning, knowledge creation and development of innovation. It is important to appropriately use the potential of employees, invest in their development, motivate them to achieve company's objectives, as well as to build a good atmosphere and friendly relationships among employees. There are a number of factors in increasing employees' creativity and innovativeness. The bigger the knowledge about the processes of creativity and innovativeness, the more productive human resources of an enterprise, and the bigger its knowledge capital and innovation capital.

In view of the above, the Author chose identification of the most important determinants shaping creativity and innovativeness of employees of Polish and Slovak economic entities as the main aim of this paper. Conclusions were based on findings of surveys conducted in the first quarter of 2017 among employees of Polish and Slovak organisations.

\section{Human capital - definitions}

Perceiving humans as capital differs from perceiving them as a resource, as capital is a financial and dynamic category. As a consequence of such an approach, employees are assessed in terms of achieved actual results, and the measure of their value is not how they meet the requirements (of the post/tasks), but their "talent" - potential, which creates added value.

Literature provides different views on human capital. As stressed by Samul (2013), this variety may result from different levels at which this concept is approached (the economy of a country, organisation, individual), the use of different research 
assumptions or changes in: the cultural context, current fashion, paradigms, metaphors, customs and language practices of a specific author and his/her times.

Human capital is the core of the activity of every organisation. It is defined as combination of knowledge, skills, innovativeness and individual capabilities of employees (Edvinsson, Malone, 1997). In the conceptual sense, human capital is one of elements the intellectual capital. Depending on the approach, other elements, namely the structural capital and the customer capital (Reed, Lubatkin, Srinivasan, 2006); structural capital which includes the organizational capital and the customer capital (SkandiaASF; OECD, 1997) structural capital and relational capital (Sveiby, 1997; Roos et al.,1997, Bontis, 1999; O’Donnell et al., 2004, 2006). Human capital refers to people with their knowledge and skills, professional experience, aspirations, motivations and attitudes; it also involves human ties, relations and relationships, level of trust and the existing culture, i.e. patterns of behaviour, norms and values (Król, Ludwiczyński, 2006, p. 118-119). According to guidelines produced within the Meritum Project, „human capital is defined as the knowledge, skills and experience that employees take with them when they leave. Some of this knowledge is unique to the individual; some may be generic. Examples are innovation capacity, creativity, knowhow and previous experience, teamwork capacity, employee flexibility, tolerance for ambiguity, motivation, satisfaction, learning capacity, loyalty, formal training and education.”(CIMA).

As stressed by Greer, Lusch \& Hitt (2017), human capital includes (aggregate): knowledge, skills, and abilities, the foundations of which are often education and personal experience of an employee. Individual human capital, according to J. Roos, G. Roos, Dragonetti and Edvinsson (1997), comprises attitudes, competences, mental capacity. Whereas in the model developed in the Scandinavian company Skandia human capital consists of such elements as competences, relations and values.

Pocztowski (2003, p.45) stresses that an organisation's human capital refers to all specific characteristics and qualities embodied in employees (knowledge, abilities and skills, health, motivation), which have a certain value and constitute a source of future incomes, both for an employee - the owner of human capital - and the organisation that uses this capital according to certain terms.

We can also encounter a view that human capital refers mainly to talented employees fully competent, well-informed, capable of taking critical decisions within an organisation (Baron, Armstrong, 2008). It should be however stressed that the owners of human capital are an organisation's employees, who decide how much to invest in the organisation in which they are employed. Roos G., Roos J., Edvinsson and Dragonetti (1997) stress that it is the reason for the increasing number of investments in human capital.

\section{Creativity and innovativeness - determinants}

Creativity and innovativeness are overlapping structures between two stages of a creative process, i.e. the phase of generation of ideas and the phase of their implementation (Brzeziński, 2009, p.36). Innovations should be perceived as a continuous process which is present in various areas of the functioning of an enterprises (Stawasz, 2000). It is visible from the moment of the inception of an idea of innovation 
to its implementation and popularisation to achieve a pre-defined objective (Niedzielski, Rychlik, 2006). An innovation process aims to ensure market success thanks to a new application of science and technology (Grudzewski, Hajduk, 2002).

As pointed out by West \& Farr (1990), innovations refer to "international implementation and use, within a role, group or organisation, of ideas, processes or procedures, which are new to a particular adoption unit and designed to bring significant benefits to an individual, group, organisation or a wider community." As pointed out by Teece (1996) emphasizes that innovation should not be considered as a one-off event but as an ongoing process, a continuous interaction between science, technology, and production.

According to Stein (1953), creativity is a process leading to new creation which is approved as useful or acceptable for a certain group in a certain period Jerzyk, Leszczyński, Mruk, 2004). It is a form of divergent thinking which looks for many possible solutions to a problem (Guilford,1966)

Creativity is defined as „(...) simply the production of novel, appropriate ideas in any realm of human activity, from science, to the arts, to education, to business, to everyday life. The ideas must be novel - different from what's been done before but they can't be simply bizarre; they must be appropriate to the problem or opportunity presented." (Amabile, 1997) Thus, creativity results in new ideas, which are novel solutions that are at the same time useful in the real world (Jerzyk, Leszczyński, Mruk, 2004). Amabile (1988) stresses that creativity is a necessary condition for the emergence of new ideas, but it differs from innovative behaviour in that it does not assume the implementation of ideas.

Creativity depends on a number of factors. As stressed by Plucker, Beghetto \& Dow (2004), creativity is interaction between capabilities, a process and environment, by means of which an individual or a group creates a specific product which is new and useful in the social context. The factors determining creativity in an enterprise are internal and external in character. They are identified at the level of an employee, taking into account their personality, work style, emotions, attitudes, motivations, interests, possessed knowledge and competences, and at the level of a team and the figure of the leader. External conditions of an organisation's creativity are created by organisations themselves and the market in which they are functioning, in particular their industry.

Within enterprises, four areas of the issues of creativity are distinguished, which should be diagnosed in terms of management possibilities and effective use. These areas, referred to as 4P, include: People, Process, Place (environment) and Product (Rhodesa, 1961), which is perceived as an effect of creativity. Jerzyk, Leszczyński \& Mruk (2004) names the following factors impacting creative thinking: team together with its leader, persons (characteristics), possessed knowledge and information gathered throughout education (knowledge of thought processes and techniques for creative problem solving); favourable environment (organisation, atmosphere), problem (inspiring, open), idea - effect of creativity.

As the human environment impacts human behaviour, the place can influence individuals' creativity and innovativeness (Martens, 2011). Chowdhury (2000) thinks that organisations have to learn how to attract and retain talented people. It can be achieved by creation of appropriate atmosphere at the workplace and appropriate relationships 
among employees. Creativity, especially in the context of achieving innovations, can be developed in different ways. An example of such activities is presented in table 1.

Table 1. Determinants of creativity in innovation

\begin{tabular}{|c|c|c|}
\hline Specification & Nature & Impact on innovation \\
\hline Knowledge & $\begin{array}{l}\text { Expert } \\
\text { general }\end{array}$ & $\begin{array}{l}\text { Expert knowledge provides a basis for an innovative } \\
\text { change, whereas general knowledge enables } \\
\text { connecting facts from other fields. }\end{array}$ \\
\hline $\begin{array}{l}\text { Intellectual } \\
\text { capacity }\end{array}$ & $\begin{array}{l}\text { Synthesis, } \\
\text { analysis, } \\
\text { presentation }\end{array}$ & $\begin{array}{l}\text { It allows one to look at a problem from many angles, } \\
\text { and then to determine the usefulness and involvement } \\
\text { and pass the idea to other people. }\end{array}$ \\
\hline Motivation & $\begin{array}{l}\text { Reinforcement of } \\
\text { action }\end{array}$ & $\begin{array}{l}\text { Hard, regular work brings effects, which are } \\
\text { innovations. }\end{array}$ \\
\hline Risk & $\begin{array}{l}\text { Operational, } \\
\text { technological }\end{array}$ & Bigger benefits in the case of success. \\
\hline
\end{tabular}

Source: Szara, K. (2014).

Szara (2014), pointed out an important role of creative employees in an organisation. She stressed at the same time that people working in an organisation have different predisposition for creativity, and more specifically to creative thinking. It means that not everybody contributes to the creation of innovations to the same extent. For instance, as stressed by Collins \& Smith (2006), of key importance for creation of new knowledge and development of innovations in high-tech companies are knowledge workers, referred to as a generation of new and useful ideas. It is their creativity that companies should focus on. Creativity, which shapes employees' innovative behaviour, consists of three basic elements: expert knowledge, creative capacity and motivation (Amabile, 1988).

\section{Research methodology}

Conclusions were based on findings of the author's own research conducted in the first quarter of 2017. The research had a form of a questionnaire. It was carried out parallel on a group of employees from Poland and Slovakia. The research employed purposive sampling. Poland and Slovakia are countries of the "former Eastern Bloc"; they completed the accession process in the same year and have been members of the European Commision since 2004. They have similar economic potential and levels of innovation, which are not high (e.g. the value of the Summary Innovation Index - SII) (more in Sipa, Lemańska-Majdzik, Okręglicka, 2016)

The below-presented findings are a fragment of wider research on problems of management of a modern enterprise. The diagnosis of the gathered data covers only variables related to pre-requisites for increasing employees' creativity and innovativeness. The following research problems have been addressed:

- Which factors are most significant for stimulating creativity of employees from both the countries? 
- $\quad$ Are there any differences in terms of the need for creativity stimulation between Polish and Slovak employees?

The research employed a questionnaire that consisted of semi-open and closed questions - dichotomic and a list of possible answers to choose from. In the questions, nominal, ratio and rank order scales were used. The questionnaire was supplemented by demographic information. Correctly and completely filled-in questionnaires were accepted for analysis: 122 questionnaires from Poland and 168 questionnaires from Slovakia.

The findings of the empirical study presented in this paper should be treated as a pilot study, as research sampling is not full representative. However, the size of the surveyed group allows for drawing initial conclusions and identifying regularities, which can be verified during proper studies.

\section{Determinants of employees' creativity and innovativeness - findings of the author's own research}

Females prevailed among those surveyed. In terms of age, young people, i.e. aged up to 25 years, dominated among the employees surveyed. In the case of the Slovak group, they accounted for just over half $(50.8 \%)$, whereas in the case of the Polish group - over $80.0 \%$. In both the groups examined, workers of services companies and manufacturing companies employed as regular employees constituted the majority. Differences could be observed in terms of an employment period. Among Slovak employees, those with an employment period not longer than 5 years $(72.2 \%)$ prevailed, with employees with over 10-year employment period accounting for $18.0 \%$. Whereas among the surveyed employees from Poland, those working for up to 5 years also dominated, but accounted for over $90.0 \%$. (tab.2)

Table 2. Characterisation of enterprises employing the respondents from Poland and from Slovak

\begin{tabular}{|c|c|c|c|}
\hline \multicolumn{2}{|l|}{ Selected characteristics } & $\begin{array}{l}\text { Poland } \\
\mathrm{n}=122\end{array}$ & $\begin{array}{l}\text { Slovakia } \\
\mathrm{n}=186\end{array}$ \\
\hline \multirow{3}{*}{ Gender } & & $(\%)$ & \\
\hline & male & 68.0 & 83.9 \\
\hline & female & 32.0 & 16.1 \\
\hline \multirow{6}{*}{ Age group } & up to 25 years old & 50.8 & 85.5 \\
\hline & 25-34 years old & 27.9 & 10.8 \\
\hline & $35-39$ years old & 16.4 & 2.2 \\
\hline & $40-44$ years old & 4.9 & 1.1 \\
\hline & 45-49 years old & 0.0 & 0.5 \\
\hline & 50 or older & 0.0 & 0.0 \\
\hline \multirow{4}{*}{$\begin{array}{l}\text { Employment } \\
\text { at the organisation }\end{array}$} & less than 1 years & 36.1 & 34.4 \\
\hline & $1-5$ years & 36.1 & 56.5 \\
\hline & $6-10$ years & 9.8 & 8.1 \\
\hline & more than 10 years & 18.0 & 1.1 \\
\hline \multirow{2}{*}{$\begin{array}{l}\text { Professional status at the } \\
\text { organisation }\end{array}$} & senior management & 11.5 & 1.6 \\
\hline & junior management & 19.7 & 18.3 \\
\hline
\end{tabular}




\begin{tabular}{|l|l|l|l|}
\hline & regular employee & 68.9 & 80.1 \\
\hline \multirow{3}{*}{$\begin{array}{l}\text { Basic type of a company's } \\
\text { activity }\end{array}$} & Manufacturing & 19.7 & 19.9 \\
\cline { 2 - 4 } & Services & 36.1 & 42.5 \\
\cline { 2 - 4 } & trade & 18.0 & 18.8 \\
\cline { 2 - 4 } & other/mixed & 26.2 & 18.8 \\
\hline
\end{tabular}

Source: Own work based on a survey

The respondents' task was to assess the importance of a range of variables in shaping their creativity and innovativeness. By awarding scores from 1 (least important) to 5 (very important), they determined individual ratings. The weighted average in both the groups surveyed did not exceed the score 4.0 and was not lower than 2.3. However, it should be noted that in the entire study, Polish employees awarded slightly higher scores. The details are presented in figure 1.

Academic literature often stresses an important role of the climate of an organisation in increasing the level of creativity and innovativeness. However, analysis of the findings shows that the determinant "climate of an organisation" was not among the top determinants facilitating creativity and innovativeness of those surveyed. Polish employees awarded it a rating of 3.254, whereas Slovak employees - 3.029. This is a rather low score, considering that academic literature highlights the importance of this factor. However, as pointed out by Nęcka (1993), a climate that facilitates creativity is "a specific combination of factors connected with the organisation of an enterprise, management style, motivation systems, communication styles and overall attitude to otherness".

The following elements are mentioned there: motivation for taking up challenges, autonomy, supporting creative ideas, openness, trust, time for implementation of ideas, humour, conflicts, debate, risk taking, dynamism (Ekvall, Ryhammar, 1999). Thus, looking at further findings, we can see a significant emphasis on selected elements comprising the climate of an organisation. 
cooperation with co-workers

support from superiors - good advice and guidance

culture of continuous learning

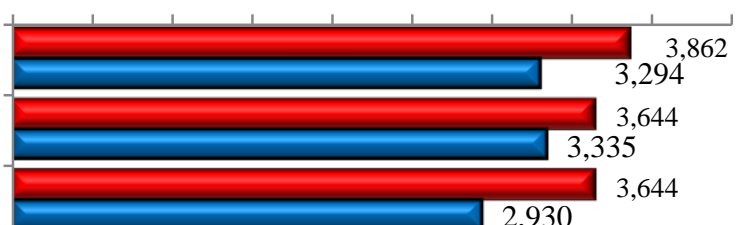

knowledge sharing

employees' freedom to come forward with proposals of..

clarity in formulation of expectations towards employees..

appropriate material resources

mutual trust

activities focused on team integration

appropriate employee resources

promoting intergenerational cooperation

employees' autonomy in performing their tasks

climate facilitating creativity and innovativeness

holding cyclical meetings to discuss proposed ideas

employees' creativity and innovative activities in a..

appropriate financial resources

clear principles for access to needed personal, capital and..

clear principles for selecting submitted proposals

employees' involvement in innovation creation

financial motivation for innovative behaviour

non-financial motivation for innovative behaviour

freedom to make mistakes

training courses to raise employees' innovativeness

conducting $\mathrm{R} \& \mathrm{D}$ works in an enterprise

cooperation in the area of innovation with external entities
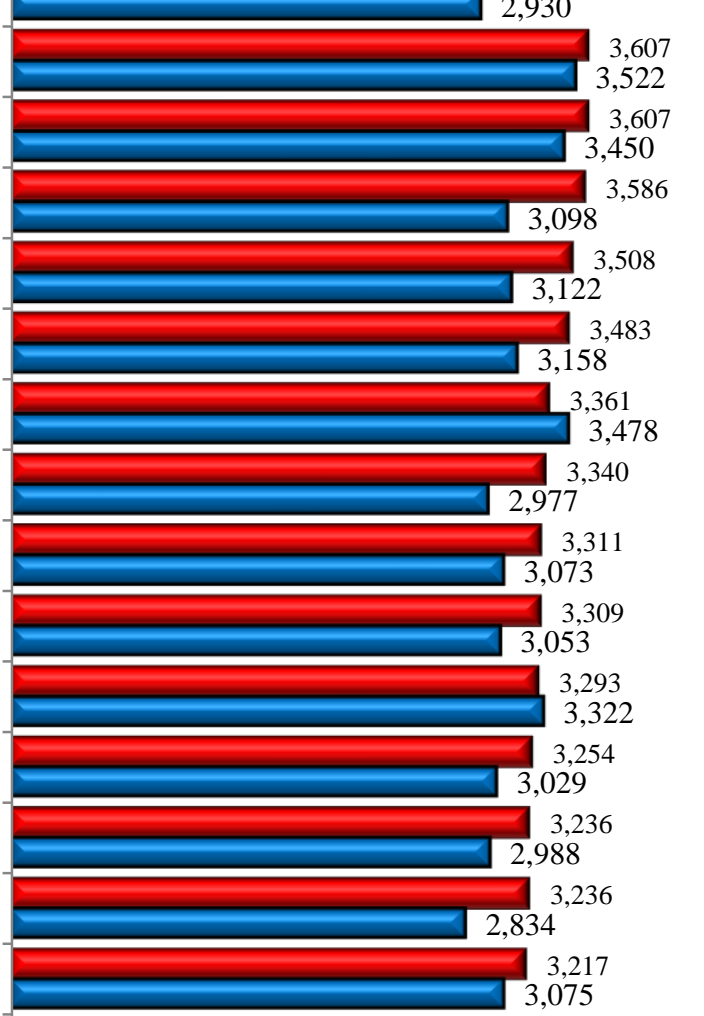

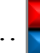

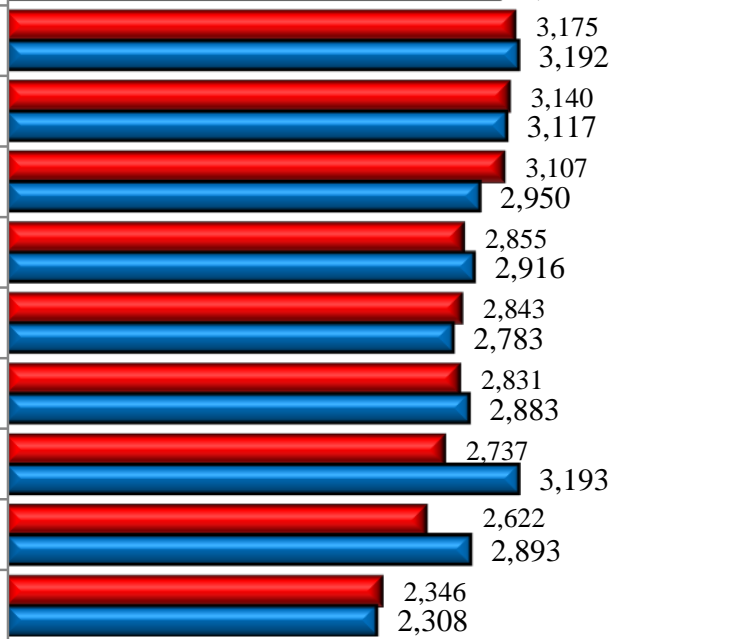

Poland $(\mathrm{n}=122) \quad$ Slovak $(\mathrm{n}=186)$

Figure 1. Evaluation of individual determinants of creativity and innovativeness by Polish and Slovake employees Source: Own work based on a survey 
Analysis of the findings shows that in the group of six most important (according to those surveyed) determinants indicated by Polish and Slovak employees, four factors overlap. These are: positive relationships between superiors and subordinates, support from superiors, cooperation with other employees and knowledge sharing. Only their hierarchy differs. (tab. 3) In the case of the survey conducted among Slovak employees, positive relationships between superiors and subordinates (3.522), mutual trust (3.478) and knowledge sharing (3.450) were found to be the most important. The six most important determinants also included cooperation with other employees, support from superiors and autonomy in performance of appointed tasks. The distribution of the answers by Polish employees was a little different. The group of six most important factors included: team work and cooperation with other employees, support from superiors and positive relationships with managers, freedom to come forward with new solutions and a culture of continuous learning. Awarded scores were also higher compared to Slovak employees.

Table 3. Most important factors shaping employees' creativity and innovativeness

\begin{tabular}{|c|c|c|c|}
\hline \multirow{2}{*}{$\begin{array}{l}\text { Poland } \\
\text { Characteristics }\end{array}$} & & Slovak & \multirow[b]{2}{*}{ Characteristics } \\
\hline & \multicolumn{2}{|c|}{$\begin{array}{l}\text { weighted } \\
\text { average }\end{array}$} & \\
\hline cooperation with co-workers & 3.862 & 3.522 & $\begin{array}{l}\text { positive relationships between the } \\
\text { manager and subordinates }\end{array}$ \\
\hline support from superiors & 3.644 & 3.478 & mutual trust \\
\hline culture of continuous learning & 3.644 & 3.450 & knowledge sparing \\
\hline $\begin{array}{l}\text { positive relationships between the } \\
\text { manager and subordinates }\end{array}$ & 3.607 & 3.335 & support from superiors \\
\hline knowledge sparing & 3.607 & 3.322 & $\begin{array}{l}\text { employees' freedom to come forward } \\
\text { with proposals of new solutions }\end{array}$ \\
\hline $\begin{array}{l}\text { employees' freedom to come } \\
\text { forward with proposals of new } \\
\text { solutions }\end{array}$ & 3.586 & 3.294 & cooperation with co-workers \\
\hline
\end{tabular}

Source: Own work based on a survey

Another group of determinants impacting the level of employees' creativity and innovativeness refers to resources possessed by an organisation: material, financial and human ones. This group of determinants was awarded scores from 3.073 to 3.159 by Slovak employees, and from 3.217 to 3.383 by Polish respondents. Human resources possessed by an organisation were ranked lower, however they occupied a slightly higher, 9th position, in the Polish ranking, coming ahead of financial resources (14 position). In the Slovak ranking of determinants, human resources occupied 14th position and were assessed as less important than financial resources - however the difference was slight. Factors connected with a motivation system as determinants encouraging employees to undertake innovative activities turned out to be less important for both the nations. What's interesting, financial motivation was more important than non-financial one. In the case of Slovak employees, financial motivation achieved the score of 2.916, whereas non-financial one - 2.783. Polish respondents awarded an average rating of 2.855 to financial forms of motivation, whereas 2.843 - to non-financial ones. 
Continuous improvement of competence and on-going learning is a necessity on today's constantly changing market. One of the elements of human capital management in an organisation is improving employees' qualifications and skills through a selection of appropriate training courses (Dzieńdziora, Smolarek, 2016). In terms of increasing employees' creativity and innovativeness, training courses to improve employees' innovative capacity scored much higher in the case of Slovak respondents. They occupied the seventh position in the ranking with a score of 3.193. In the case of Polish employees, such training courses came 21, with a score of 2.737 .

Cooperation with other employees and knowledge sharing were rated high by both the groups surveyed, but intergenerational cooperation, which combines older employees' experience and "expert" knowledge with young employees' fresh take and knowledge, scored relatively poorly. Promotion of this type of cooperation is especially important these days, as enterprises increasingly suffer from staff shortages, in particular they lack talents (Tupá, 2013). The problem of shrinking staff plagues both the Polish and Slovak economies. Benefits of promoting intergenerational cooperation were rated higher by Polish employees (3.309).

In the case of the least important factor, employees from both the countries examined showed a full agreement. According to those surveyed, whether a company cooperates with external entities to create innovation is least important. The score of that factor was 2.3.

Polish employees also highlighted clarity in formulation of expectations towards employees in terms of their innovativeness and creativity. This factor achieved a score of 3.508. Further, analysis of the assessments by Polish employees shows that the determinants with a score of above 3.0 included an element of control, more specifically the suggestion that evaluation of creativity and undertaken innovative activities should be part of periodical staff appraisal. In the case of Slovak employees, these factors were less important. Clarity in formulation of expectations towards employees in terms of their innovativeness and creativity achieved a score of 3.122, whereas inclusion of the evaluation of creativity and undertaken innovative activities in periodical staff appraisal only 2.834 points.

\section{Conclusion}

In today's, fast changing competitive world, creativity and innovativeness are of key importance, both at micro, society and macro levels. Shrinking and ageing labour force adds to the problems of modern economies and enterprises. Of importance is also the quality of such resources, which should constitute human capital for an organisation. Human capital is a driving force for development, containing huge motivation possibilities, which can be revealed when a company is effectively managed in line with its mission and strategic objectives (Skibiński, 2017). It is thus important for organisations to pay special attention to proper management of human capital through increasing its creativity and innovativeness. Creation of an innovative culture should combine objectives, values and differences in an organisation (Trompenaars, 2010). Analysis of the findings of the survey shows that: 
- $\quad$ For both the examined groups, the six most important determinants included factors connected with the climate of an organisation.

- The answers provided in the survey also confirmed the important role of a manager and his/her attitude to employees in an organisation.

- Both Polish and Slovak employees indicated autonomy and necessity of cooperating with other employees and sharing knowledge.

- Despite a significant prevalence of young employees in the Polish group compared to the Slovak group, promotion of intergenerational cooperation to increase creativity and innovativeness scored higher in the case of Polish employees.

- $\quad$ The survey also pointed out minor importance of financial and non-financial motivation in the area examined. Evaluation by Polish and Slovak respondents was similar and did not exceed 3 points on a five-point scale.

Identification of factors that are significant in terms of stimulating employees' creativity and innovativeness enables indication of the directions of activities to be taken by managers. We should however bear in mind that not all employees have the same level of creativity development, which can then be translated into innovation.

\section{Acknowledgments}

Thanks to dr Tupa from Alexander Dubcek University of Trencin, for support in carrying out the survey.

\section{References}

Amabile, T.M. (1988). Model of Creativity and Innovation in Organizations. Research and Organizational Behavior, vol.10, pp.123-167.

Amabile,T. M. (1997). Motivating creativity in organizations: On doing what you love and loving what you do. California Management Review, 40(1), pp. 39-58.

Baron, A., Armstrong, M. (2008). Zarz̨adzanie kapitatem ludžkim. Kraków: Oficyna Wolters kluwer Business.

Betakova, J., Dvorsky, J., Haviernikova, K. (2014). Social Capital and Safety Perception as Aspect of Improving Regional Competitiveness of Territory In: Zhang Y. (ed.). 2nd International Conference on Management Innovation and Business Innovation (ICMIBI 2014), Book Series: Lecture Notes in Management Science, Vol. 44, pp. 68-73.

Bontis, N. (1999). Managing organizational knowledge by diagnosing intellectual capital: framing and advancing the state of the field. International Journal of Technology Management. Vol. 18 Nos 5-8, pp. 433-462.

Brzeziński, M. (2009). Organizacja kreatywna. Warszawa: Wydawnictwo Naukowe PWN.

Chowdhury, S. (2000). Towards The Future of Management, In: Chowdhury, S., (Ed.) Management 21 C., Financial Times, London: Prentice Hall.

CIMA. Understanding corporate value: managing and reporting intellectual capital, Available at http://www.cimaglobal.com/Documents/ImportedDocuments/intellectualcapital.pdf

Collins, C.J., Smith, K,G. (2006). Knowledge exchange and combination: The role of human resource practices in the performance of high technology firms. Academy of Management Journal, 49, pp. 544-560.

Dzieńdziora, J., Smolarek, M. (2016). Contemporary Challenges of Human Resources Management in Small and Medium Enterprises in Conditions of European Integration on the Example of Region of Silesia in Poland In: 2International Conference on European Integration 2016 Ostrava, Czech Republic, p. 182-189. 
Edvinsson, L. Malone, M.S. (1997). Intellectual Capital: The Proven Way to Establish Your Company's Real V alue by Measuring Its Hidden Brainpower. Lodon: Piatkus.

Ekvall, G., Ryhammar, L. (1999). The Creative Climate: Its Determinants and Effect at a Swedish University. Creativity Research Journal, vol. 12, no 4, pp. 303-310.

Gorzeń-Mitka, I. (2016). Leading Risk Management Determinants of Small and Medium-Sized Enterprises (SMEs): An Exploratory Study in Poland. Eurasian Studies in Business and Economics, 3(1), pp. 289-298.

Greer, Ch., Lusch,R., Hitt, M.A. (2017) A Service Perspective For Human Capital Resources: A Critical Base For Strategy Implementation, Academy of Management Perspectives. Vol. 31. pp.137-158. Available at https://doi.org/10.5465/amp.2016.0004.

Grudzewski, W.M., Hajduk, I.K. (2002). Innowacyjność w technice i technologii 乏̌ródtem przewagi konkurencyjnej matych $i$ średnich przedsiębiorstw. Warszawa: Instytut Funkcjonowania Gospodarki Narodowej.

Guilford, J. P. (1966). Intelligence: 1965 model. American Psychologist, 21, pp. 20-26.

https://www.oecd.org/sti/ind/1948022.pdf

Jerzyk, E., Leszczyński, G., Mruk, H. (2004). Kreatywność w bižnesie. Poznań: Wydawnictwo Akademii Ekonomicznej w Poznaniu.

Król, H., Ludwiczyński, A. (2006). Zarzadzanie zasobami ludžkimi. Tworzenie kapitatu ludžkiego organizacji. Warszawa: PWN.

Lanvin, B., Evans, P. (eds). (2015). The Global Talent Competitiveness Index2017. Talent Attraction and International Mobility. INSEAD. Fontainebleau, France. Available at http://global-indices.insead.edu/gtci/ documents/ gcti-report.pdf.

Martens, Y. (2011). Creative workplace: instrumental and symbolic support for creativity. Facilities, 29(1/2). pp. 63-79.

Mynarzova, M., Stverkova, H. (2015). Public Support As An Important Factor For Competitiveness Of SMEs In The European Union, Conference on Current Problems of the Corporate Sector Location: ModraHarmonia, Aktualne Problemy Podnikovej Sfery, pp. 452-461 .

Nęcka, E. (1993). Twórczość w przedsiębiorstwie i organizacji, in: Strategie w biænnesie, Sedlak, K. Ed. Kraków: Wydawnictwo Profesjonalnej Szkoły Biznesu.

Niedzielski, P., Rychlik, K. (2006). Innowacje i kreatymność. Szczecin: Wydawnictwo Naukowe Uniwersytetu Szczecińskiego.

Nonaka, A.J., Takeuchi, H. (2000). Kreowanie wiedsy w organizacji. Warszawa: Poltext.

O’Donnell, D., Bontis, N., O’Regan, P., Kennedy, T., Cleary, P. and Hannigan, A. (2004). CFOs in eBusiness: eArchitects or foot-soldiers?. Knowledge and Process Management. Vol. 11 No. 2. pp. 10516.

O’Donnell, D., Tracey, M., Henriksen, L.B., Bontis, N., Cleary, P., Kennedy, T. and O'Regan, P. (2006), On the 'essential condition' of intellectual capital-labour. Journal of Intellectual Capital. vol. 7 No. 1. pp. $111-28$.

OECD (1997). The Danish Trade and Industry Development Council, Intellectual Capital Accounts. Reporting and managing intellectual capital, Memorandum May, p.37, Available at

Plucker, J. A., Beghetto, R. A., Dow, G. (2004). Why isnt creativity more important to educational psychologists? Potential, pitfalls, and future directions in creativity research. Educational Psychologist 39. p. 83-96.

Pocztowski, A. (2003). Zarzadzanie zasobami ludzkimi. Warszawa: PWE.

Reed, K.K.., Lubatkin, M., Srinivasan, N. (2006). Proposing And Testing An Intellectual Capital-Based View Of The Firm. Journal Of Management Studies. Vol. 43, (4). p. 867-893.

Rhodes, M. (1961). An analysis of creativity. Phi Delta Kappan, 42(7), pp. 305-310.

Roos, J., Roos, G., Dragonetti, N.C., Edvinsson, L., (1997). Intellectual Capital. Navigating the New Business Landscape. Macmillian Press.

Samul, J. (2013). Definicje kapitału ludzkiego w ujęciu porównawczym. Zessyty Naukowe Uniwersytetu Pryyrodniczo-Humanistycznego w Siedlcach. Nr 96 Seria: Administracja i Zarządzanie (23). p. 195-204.

Sipa, M., Lemańska-Majdzik, A., Okręglicka, M. (2016), Factors Differentiating the Level of Innovation of the Visegrad Group Countries In: 2International Conference on European Integration 2016 Ostrava, Czech Republic, p. 858-866.

Skandia ASF. A sample from the Skandia AFS case study, p. 4. Available at http://oktato.econ.unideb.hu/domician/Downloads/eset/Skandia.pdf; 
Skibiński A. (2017). The Changes of the Population Structure and Its Consequences in Selected EU Countries - Some Aspects. European Journal of Sustainable Development, Vol. 6 (1). pp. 357-368.

Stawasz, E. (2000). Innowacje a mała firma. Lódź: Wydawnictwo UŁ.

Stein, M.I. (1953). Creativity and culture. The Journal of Psychology, 36, pp. 311-322.

Sveiby, K.E. (1997), The New Organizational Wealth: Managing and Measuring Knowledge-Based Assets. New York: Berrett-Koehler.

Szara, K. (2014). Kreatywność a innowacyjność w działalności podkarpackich przedsiębiorców, Zeszyty Naukowe Matopolskiej Wẏ̇szej Szkoty Ekonomicznej w Tarnowie, t. 24, nr 1. p. 201-201.

Teece, D.J. (1996). Firm organization, industrial structure, and technological innovation. Journal of Economic Behaviore Organization. Vol. 31, pp. 193-224.

Trompenaars, F. (2010). Kultura innowacji. Kreatywność pracowników a sukces firmy. Warszawa: Oficyna a Wolters Kluwer business,.

Tupá, M., (2013). Talent Management In: Innovation Processes in Orgnizations, Eds. Masárová T., Strunz H., Vojtovič. Wien/Berlin: MERCUR VERLAG, p. 255-276.

Van de Ven, A. H. (1986). Central problems in the management of innovation. Management Science, 32. pp.590-607.

West, M.A., Farr, J.L. (1990). Innovation and creativity at work: Psychological and organizational strategies. Chichester: John Wiley. 